\title{
Chapter 9 \\ Rhetoric and Argumentation \\ in the Pandemic Legislation: The Italian \\ Case
}

\section{Federico Puppo, Silvia Corradi, and Lorenzo Zoppellari}

\begin{abstract}
This chapter examines the argumentative and rhetorical structure of the regulatory techniques used to deal with the SARS-CoV-2 pandemic in Italy. The first part of the chapter aims to clarify the connection between law and rhetoric, in order to provide a framework in which the legislative activity has operated. After analyzing critical aspects of the chosen regulatory tools, we will focus on the three most innovative elements of the pandemic legislation: the frequent use of images, the sporadic presence of sanctions, and the relevant role of experts. In the second part, an analysis of the fundamental traits of visual argumentation will be presented to highlight the fact that the use of images, during the pandemic period, has become a political-normative technique, which is never a neutral tool, but is always subject to interpretation and endowed with a notable rhetorical value. Given the sporadic presence of sanctions, the second section will analyze the argumentative strengthening applied by the legislator in order to promote the obedience of the recipients of the measures. Finally, we will examine the involvement of experts in the justificatory activity of the legislator, and the need for them to acquire legislative legitimacy through a rhetorical-argumentative relationship with citizens.
\end{abstract}

Keywords Covid-19 Italian legislation - Justification of law $\cdot$ Legal rhetoric • Visual argumentation $\cdot$ Soft law

\subsection{Introduction}

The SARS-CoV-2 pandemic-henceforth COVID-19-appeared in all its severity in Italy on 31st January 2020: by a resolution of the Council of Ministers, a state

F. Puppo $(\bowtie) \cdot$ S. Corradi $\cdot$ L. Zoppellari

Faculty of Law, University of Trento, Trento, Italy

e-mail: federico.puppo@unitn.it

S. Corradi

e-mail: silvia.corradi@unitn.it

L. Zoppellari

e-mail: lorenzo.zoppellari@unitn.it

S. Oswald et al. (eds.), The Pandemic of Argumentation, Argumentation Library 43,

https://doi.org/10.1007/978-3-030-91017-4_9 
of emergency was declared due to the health risks associated with the outbreak of infectious diseases. The state of emergency was then extended until 31st January 2021 (Law Decree no. 125/2020) and again until 30th April 2021 (Law Decree no. $2 / 2021$ ). The period defined by this "regulatory pandemic" is the subject of this essay. During this period, the link between making and communicating law emerged in all its intensity (Gazzolo, 2020) and it reinforced the disappearance of the idea of law as a mere authoritative act subject to sanctions (Ferraro \& Zorzetto, 2018, 3). The analysis of the norms that have characterized (and still characterize) the emergent pandemic period seems to confirm our starting assumption: so, it is considered appropriate to start with them in order to fully understand the rhetorical value of the legislative strategies chosen by the Italian Government. The intersection between public institution and argumentation is not, however, a novelty but a complex series of normative phenomena that originate from the post-war period, when the transition from the juridical culture of legal certainty to the culture of the justification of law began (Luzzati, 2018; Pino, 2017). This step has become irreversible with the constitutionalization of legal systems and with the most recent emergence of legal pluralism (typical, for example, of the relations of states within the EU and between the European institutions and the states themselves), which showed all the limitations of the Kelsenian model of legal order (mainly hierarchical and static), until then dominant (e.g. Delmas-Marty, 1986). In this context, the role of the legislator has also changed, because it increasingly needs to justify the rules on a rhetoricalargumentative basis. It is sufficient in this sense to look at the form of the various legislative measures which have increasingly become measures preceded or accompanied by the justification for the choices made, as is the case for example in the Preambles to the legislation or in the increasingly widespread phenomenon of softlaw, typical of EU law but also of national legislations. It is about that complex of activities in which the so called "legisprudence" is realized (Wintgens, 2006). This approach is able to emphasize the rhetorical value of the communication of the legislator, which took on a peculiar role in Italy during the management of the COVID-19 pandemic. In this context, the role played by the bond of trust between citizens, legislator and political institutions also appeared in all its importance. In fact, thanks to this connection, legislator and political institutions are able to create their «anterior groundwork of ethos building» (Kjeldsen, 2018, 279), which «depends on multiple factors: the purposes they pursue, their history, reputation, efficiency and the ability to respond to the expectations of their interlocutors» (Belardinelli \& Gili, 2020, 86).

By moving from this legal philosophical background, the essay will first reconstruct the main three legislative activities issued in Italy to deal with the pandemic emergency (Sect. 9.1), emphasizing peculiarities connected with the role of rhetoric: frequent use of images; media activity to introduce and justify the dispositions; massive involvement of experts (Sect. 9.2). We will then dedicate a specific part of the research to each of these peculiar characteristics, which corresponds to a precise rhetorical purpose: Sects. 9.3-9.5 will be dedicated to the rhetorical role played by the use of images to support the legislative action; Sects. 9.6 and 9.7 will deal with the 
argumentative strengthening put in place by the legislator to encourage the compliance with the restrictive norms introduced; Sect. 9.8 will deal with the role delegated to the experts within this legislator's rhetorical-argumentative activity. Finally, Sect. 9.9 will present some conclusions in order to underline possible changes due to the new legislative paradigm analyzed in our chapter.

\subsection{The Need for Justification}

In the case-study of the pandemic it is possible to note, on one hand, the passage from the juridical culture of legal certainty to the culture of the justification of law, and, on the other hand, the sunset of the hierarchy of law. They both are elements able to be a possible cause for the appearance of the rhetorical legislative activity, mainly during the state of emergency due to the pandemic. In this case of emergency, in fact, the legislator needed to reinforce the justification of the provisions (through imagines, media, and so on, as we will explain afterwards) and so to stress the connection between law and rhetoric, due to some forms of lack of formal legitimacy in the legislative activity. In order to start with a framework of the situation, a premise is necessary, which deals with the status of the sources of law in the Italian system. It is a hierarchy of sources of law, where, according to the Kelsenian and pyramidal view of legal order, every level of the pyramid has to respect the regulations in the superior level. Very briefly, we can summarize the hierarchy as follows. The higher level of status of law is the constitutional one: norms in the Constitution can be derogated, in some specific cases and respecting certain conditions, by the source of "primary status" only — and not by "secondary status law"; then there are sources of "primary status" (it includes ordinary law but also Law Decrees, the legislative tool seldom used during the pandemic to derogate the constitutional provisions); finally there is the "secondary status law" (in this level there are the Decrees of the President of the Council of Ministers, which formally cannot derogate constitutional or primary status provisions at all, but actually were frequently adopted during the pandemic due to their short promulgation process). Cassese (2021), a prominent Italian jurist, has underlined that the Government preferred to issue continuous and strict Decrees of the President of the Council of Ministers (D.P.C.M.), limiting constitutional rights (as the freedom of movement or of economic initiative).

Such a choice is highly controversial from a constitutional point of view and, as mentioned in the introduction, it has modified the static-hierarchical model of legal order. It means that the hierarchy of sources of law has been violated: for instance, the limitations connected to the basic freedom of movement (art. 16 of the Italian Constitution) were allowed, by the Law Decree n. 6/2020, in local areas and not in the entire Italian territory. The next D.P.C.M. (which is a "secondary status law" and therefore could not contradict neither the Law Decree, nor the constitutional provisions), since the 9th of March, introduced strict limitations on the entire Italian territory (Gatta, 2021). Therefore, the measure, as many others, was not authorized by the superior law and it has broken not only the balance between legislative 
authorities (e.g. Parliament and President of the Council of Ministers) but also the hierarchy of the legal system itself. In this complex situation, it appears that Italian legislator, on the one hand, often used these inferior regulatory sources to simply encourage, even with the use of images, best practices to avoid the spread of the virus (without providing for sanctions, and therefore basing the effectiveness of such measures solely on their persuasive effect); and, on the other hand, she engaged in an argumentative reinforcement of the provisions issued through the lower sources, with the aim of increasing their normative power (Andone \& Greco, 2018). In fact, this argumentative reinforcement seems to be needed: norms must search for their prescriptiveness, and in such a situation, since the legal hierarchy of the system was not respected, they need to be justified by using rhetoric.

\subsection{Changes in Law: Images, Sporadic Sanctions, and Experts ${ }^{1}$}

In order to understand the rhetorical-argumentative changes, it is worth to start by a short analysis of the normative pandemic framework. It is possible to notice three different innovative aspects in the normative pandemic: namely, images that were provided, the lack of sanctions in the normative provisions and the prominent role of experts.

In the following sections there will be a focus on the most representative of them, namely the role of images; but, in order to provide any examples, we can remember that some provisions dedicated to the rules for cruise ships (dated 24th October 2020 and 3rd November 2020), have made use of images showing how to behave to prevent the spread of the virus. Images are also present in the Ministerial Decree of 26th April 2020, which requires manufacturing and commercial activities to display specific precautionary signs inside their business premises in order to remind personnel to respect the measures provided (such as, for example, the obligation to sanitize hands and the obligation to maintain safety distances).

The second peculiarity of pandemic legislation deals with the fact that in large parts of the legislation there is a lack of sanctions. Eighty-five acts have been issued, and sanctions have been sporadic:

Article 3, paragraph 4 of Legislative Decree no. 6/2020 provides for the arrest of, or a fine for anyone who fails to comply with the containment measures.

Article 4 of Legislative Decree no. 19/2020 (which is recalled in Law Decree no. 1/2021, 2/2021, 12/2021 and 15/2021) provides for administrative sanctionscriminal sanctions in cases which are considered to be a serious offence.

\footnotetext{
${ }^{1}$ Legal references are taken from the Official Gazette of the Italian Republic: https://www.gazzet taufficiale.it/attiAssociati/1/?areaNode=12. Consulted on 16.3.2021.
} 
Article 2 of Law Decree no. 33/2020 refers to the administrative sanction of Law Decree no. 19/2020, unless the act constitutes an offence under Article 650 of the Criminal Code.

These sanctions, which can be found in the abovementioned Law Decrees, are not indicated in the D.P.C.M., even if the latter, as mentioned, has often modified the content of the former. This is an example of what was explained above: the role of the sanction is weakened and the law-making is changing.

Lastly, the role of experts has become predominant. In particular, the Scientific Technical Committee (in Italian, C.T.S.) was appointed for the first time by means of the Ministerial Decree of March 2020, following the declaration of the state of emergency. It has been established that, in order to face the emergency, the Head of the Department of Civil Protection is to coordinate all necessary interventions with the assistance of the C.T.S. (art. 2, Ordinance of 3rd February 2020), chaired by the Secretary General of the Ministry of Health. ${ }^{2}$

The decisional weight of this Committee has varied according to the content of the measures, and three possible variants of differing significance can be identified:

1. In many cases, the C.T.S. resolutions are referred to in the epigraph of the decree (see Ministerial Decrees dated 1st March 2020, 13th October 2020, 3rd December 2020).

2. In other cases, a series of criteria are drawn up by the C.T.S. itself, which are incorporated into the Ministerial Decree and therefore acquire legal value (e.g. Ministerial Decree dated 11th June 2020 and Ministerial Decree of 3rd December 2020).

A more significant weight is attached to actual scientific publications of the C.T.S., which acquire legal value once they are inserted within the Ministerial Decree, with an interesting combination of science and law (for example, the Ministerial Decree dated 2nd March 2021 provides a series of images, graphs and tables to explain the phases of the pandemic in Italy, the solutions adopted and possible future scenarios).

\subsection{Image Rhetoric in the Management of the COVID-19 Emergency}

The use of images in the management of the COVID-19 emergency appears to be one of the most interesting factors from a rhetorical-argumentative point of view: brochures, posters, infographics and diagrams designed by institutional bodies and the government have now become the mainstay of official communication and, even more so, of the urban landscape and buildings. Anyone, not only in Italy, has certainly stopped to look at and followed the instructions given by images such as those

\footnotetext{
${ }^{2}$ The complete list of expert members of the C.T.S. can be found on the website: http://www.sal ute.gov.it/portale/nuovocoronavirus/dettaglioContenutiNuovoCoronavirus.jsp?lingua=italiano\& $\mathrm{id}=5432 \&$ area $=$ nuovoCoronavirus \&menu=vuoto. Consulted on 15.4.2021.
} 


\section{How to Handwash?}

WASH HANDS WHEN VISIBLY SOILED! OTHERWISE, USE HANDRUB

Duration of the entire procedure: $40-60$ seconds

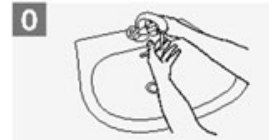

Wet hands with water;

3

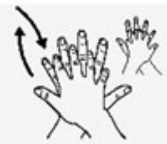

Right palm over left dorsum with interlaced fingers and vice versa;

6

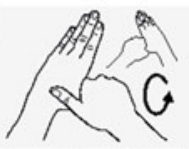

Botational rubbing of left thumb clasped in right paim and vice versa:

9

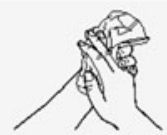

Dry hands thoroughly with a single use towel;
1

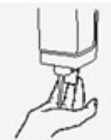

Apply enough soap to cover all hand surfaces;

4

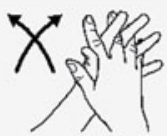

Paim to paim with fingers interlaced.

7

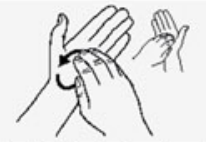

Rotational rubbing, backwards and fonwards with clasped fingers of night hand in left palm and vice versa;

10

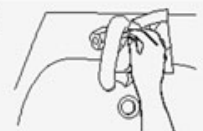

Use towel to turn off faucet:
2

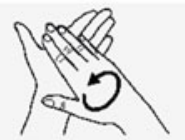

Rub hands palm to palm;

5

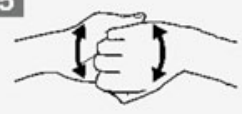

Backs of fingers to opposing paims with fingers interlocked;

8

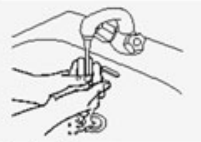

Rinse hands with water

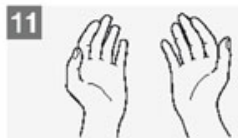

Your hands are now sate.

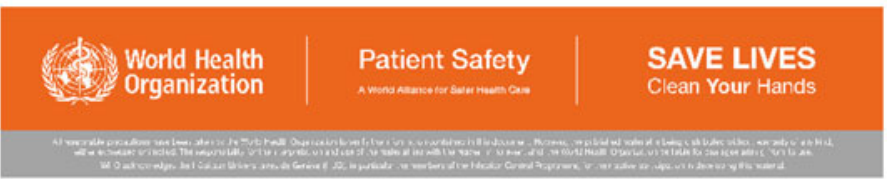

Fig. 9.1 Handwash method by the World Health Organization

developed by the World Health Organization ${ }^{3}$ (Fig. 9.1) or, in the case of Italy, by the Italian Ministry of Health ${ }^{4}$ (Fig. 9.2).

Such images are as numerous as they are varied, and we take their ubiquitous presence and use as commonplace. As stated before, such images have become an integral part of certain legislative measures and were published in the Official Gazette of the Italian Republic: evidence of this fact can be found in the already mentioned

\footnotetext{
${ }^{3}$ https://www.who.int/teams/integrated-health-services/infection-prevention-control/hand-hyg iene/training-tools Consulted on 10.4.2021.

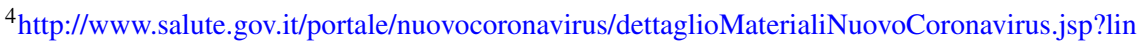
gua $=$ italiano\&id=28\&area=nuovoCoronavirus\&menu=vuoto Consulted on 10.4.2021.
} 


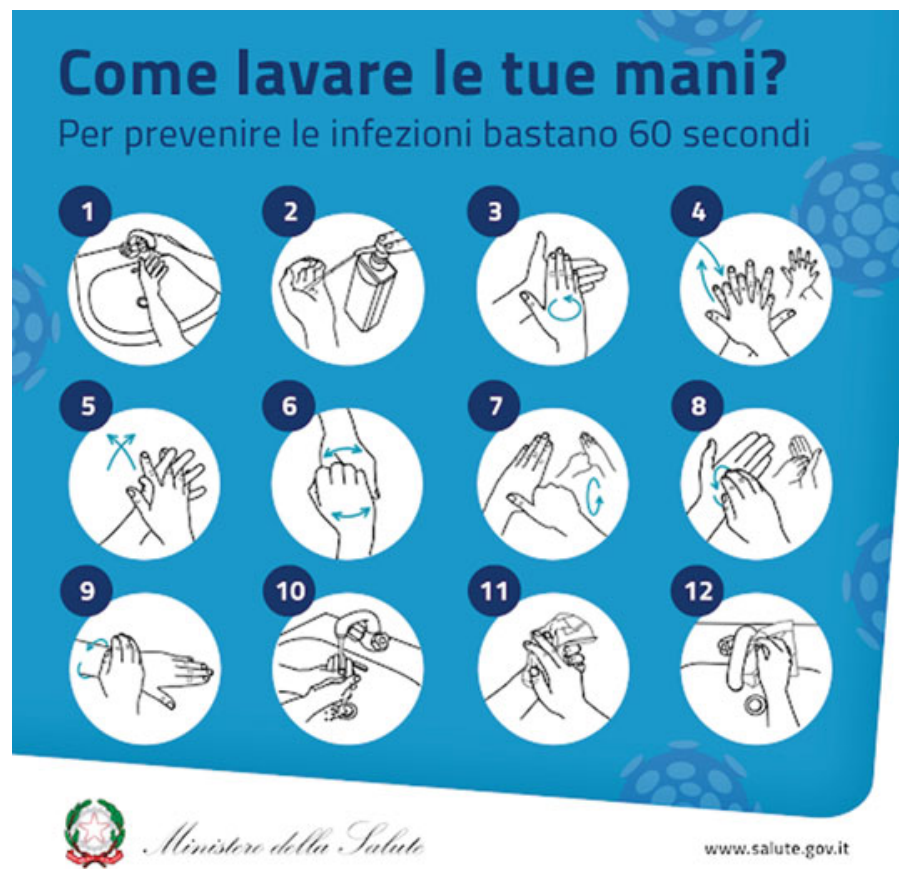

Fig. 9.2 Handwash method by the Italian Ministry of Health

D.P.C.M. of November 2020, whose appendices are the same as those contained in the Guidance for Ship Operators for the Protection of the Health of Seafarers of the International Chamber of Shipping. ${ }^{5}$ As examples, see Figs. 9.3 and 9.4.

It should also be noted that updates on the evolution of the pandemic and contagions in Italy was one of the duties of the Civil Protection Department (CVD), a structure of the President of Council and it acts in relationship with its decision, which has been in charge of communication and operational tasks. Every day, the CVD held an evening press conference during which it informed the country of the spread of COVID-19 and the hospital situation: such information is, from a strict formal point of view, different from legislation, but, from a substantial point of view, it can be considered as part of the legislative action of the Italian Government and Ministries (this point will be analyzed also in Sect. 9.7). The pandemic data, updated every $24 \mathrm{~h}$, were summarized on the interactive dashboard on the Civil Protection Department's website. ${ }^{6}$ Figure 9.5 represents the dashboard updated as of 14 th April 2021.

\footnotetext{
${ }^{5}$ https://www.ics-shipping.org/wp-content/uploads/2020/11/covid19-guidance-for-ship-operatorsfor-the-protection-of-the-health-of-seafarers-v3-min.pdf. Consulted on 14.4.2021.

${ }^{6} \mathrm{https}: / /$ opendatadpc.maps.arcgis.com/apps/dashboards/b0c68bce2cce478eaac82fe38d4138b1, consulted on 14.4.2021.
} 
Fig. 9.3 International chamber of shipping example 1

Fig. 9.4 International chamber of shipping example 2
COVID-19

How to safely

greet others

Avoid physical contact.

Safe greetings include

a wave, a nod

or a bow

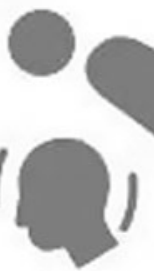

For mora information go to

ics-shipping-org/covidis

\section{International}

\section{Chamber of stipping}

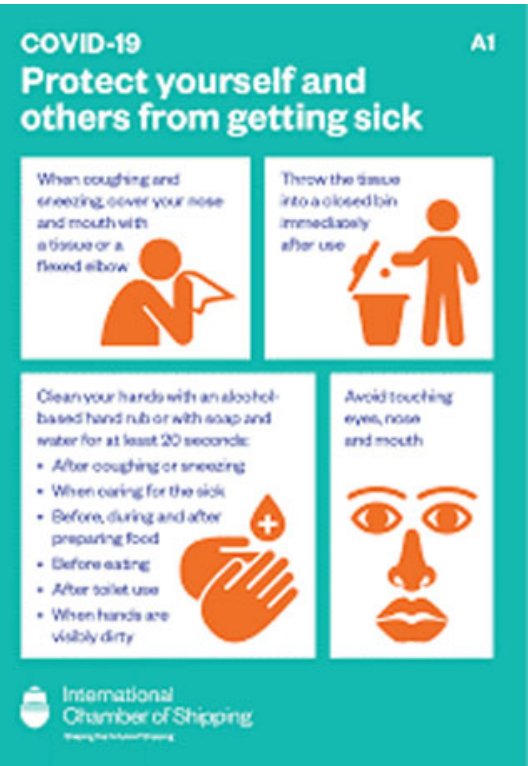




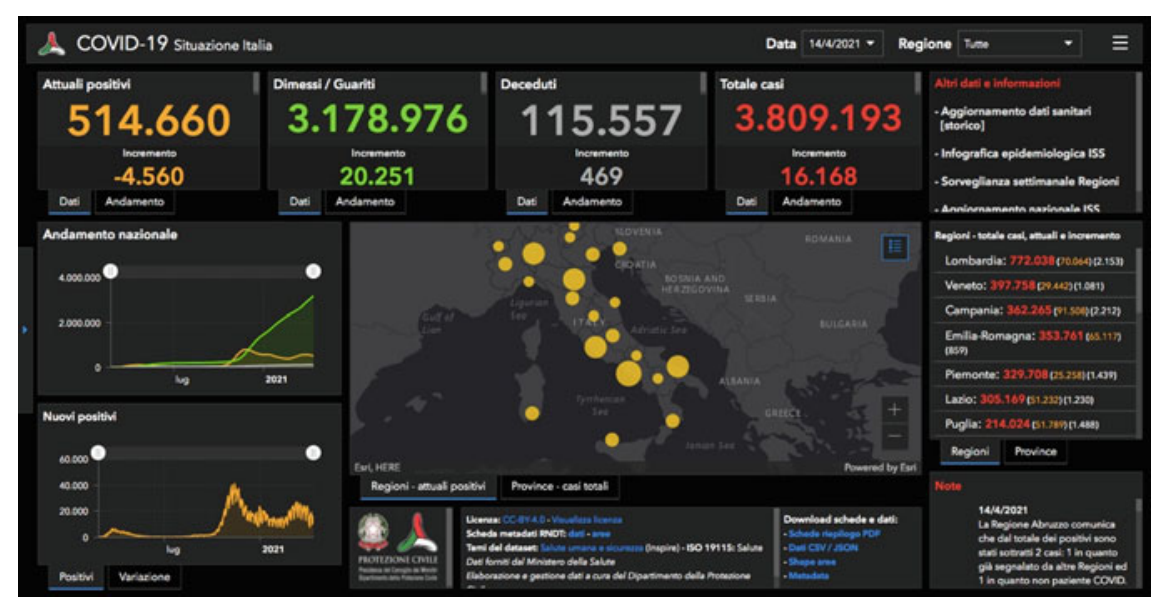

Fig. 9.5 Interactive dashboard

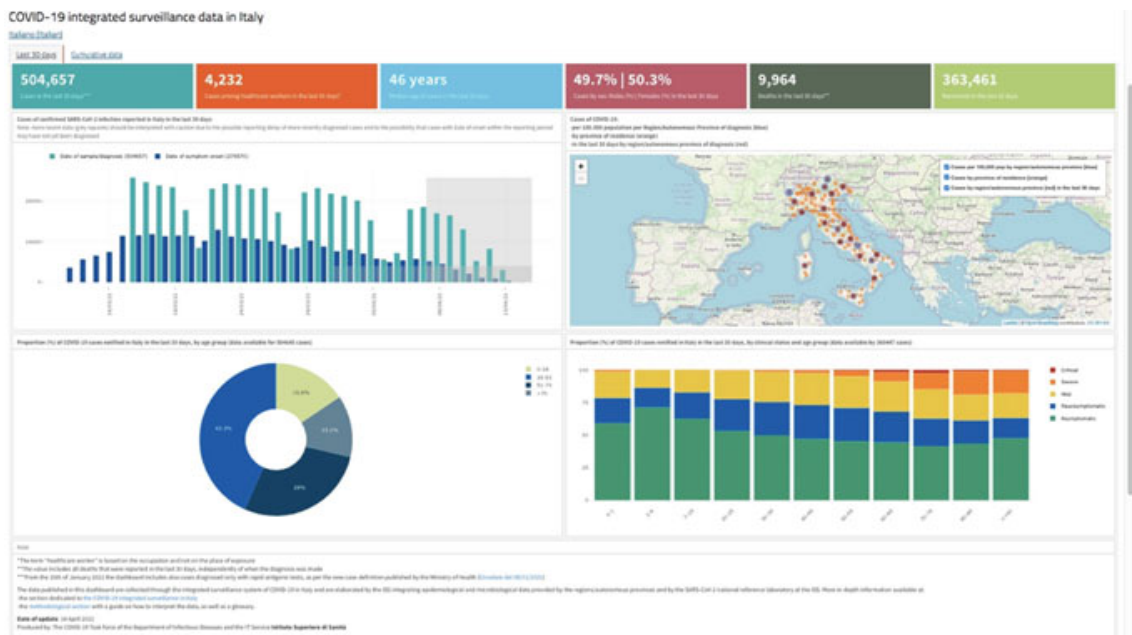

Fig. 9.6 Updated infographic

The Italian National Institute of Health also relayed official communications through specific infographics, such as the data of the COVID-19 Integrated Surveillance in Italy. ${ }^{7}$ Figure 9.6 represents the updated infographic as of 14th April 2021.

The use of images is a confirmation of the importance of visual tools as part of official political and legal communication, which can be argumentative or, even more so, rhetorical.

\footnotetext{
${ }^{7}$ https://www.epicentro.iss.it/en/coronavirus/sars-cov-2-dashboard, consulted on 14.4.2021.
} 
From this point of view, it should be noted that «pictures are able to provide vivid presence (Latin evidentia), realism and immediacy in perception, which is difficult to achieve with words only» (Kjeldsen, 2013, 4). In many cases, it can even be argued that «photographs, and other non-verbal phenomena are the best way to express what is impossible to say in words» (Groarke, 2017, 10).

But, from a certain point of view, it can be said that we may have different kind of evidence and realism in photographic images, infographics or dashboards. Just look at this from a rhetorical perspective: photographic images could have a deep impact because of their beauty, and so aiming at engaging emotions and pathos. Then, looking at a photographic image means takinginto consideration the photographer, it means the subjective perspective by which the image is taken. Photographic images are representation of the world. At the other side, we have infographic and dashboard: they seem or pretend to be a 'simple' collection and, more than representation of data, presentation of them, with a sort of claim for objectiveness (we will say more on that in the next section). At the same time, it can be said that a certain kind of 'pictorial beauty' could be found in them: this particular kind of — as can be said by having in mind the subject who produces them-institutional images, «by the simple fact that they organize and articulate and give visual presence to information, use rhetorical means» (Kinross, 1985, 19), such as colors, pictograms and so on, in order to present data in a pleasant way. The above-presented Fig. 9.6, in black-and-white (Fig. 9.6b is), would surely have a different kind of impact, because «it is hard to think of anything that is more like a rhetorical device than this use of color» (Kinross, 1985, 20):

But, more than pathos, what seems here to be at stake is probably more related to ethos: in fact, infographics and dashboards «say something about the nature of organization that publishes them» (Kinross, 1985, 21). To present data in a pleasant way is a mean to appear efficient, trustworthy and reliable: something that is crucial in a particular historical period like the one of pandemic, mainly for lawmakers who need to benefit from the trust of people (even more if we consider that effectiveness of pandemic regulation, also due to the infringement of the Kelsenian hierarchy, depended more on the bond of trust between institutions and citizens, than on sanctions-we will return to this point in Sects. 9.7 and 9.8, also with reference to the concept of "accountability").

Also from this point of view, such communications can be more immediate and effective, precisely because of the clarity that words often lack. The following section will be devoted to further consideration of this aspect, being aware that

moving beyond representation means shifting from an epistemological treatment of visuals to an ontological one. Such a move would "collapse the distance between presentation and representation: the image is the presentation" (Daston, 2014: 320-21). In part, this is to acknowledge that visuals are performative (MacKenzie, 2006), that they don't just represent, they also constitute or coproduce (Jasanoff, 2004) the objects we encounter in the world (Brennen et al., 2021, 281). 


\title{
9.5 Showing Is Not Saying
}

Jurists have long discussed the nature of legal language, which possesses the ineradicable characteristic of being vague (Puppo, 2012). ${ }^{8}$ This is, in fact, a general feature of any language: our «verbal code [...] is necessarily approximate and imprecise. In contrast, multimodal representations of the world attempt to present reality in a way which is particular rather than generic» (Groarke, 2017, 22). The difference is substantial: images can aspire to clarify what words struggle to achieve:

\begin{abstract}
We can understand these differences in terms of Wittgenstein's distinction between saying and showing. In describing an action, an event or a thing verbally, we look for words that will allow us to say what it is like. [...] [T]his is a task that language accomplishes in a way that is inevitably approximate and vague. These limits are eliminated (or at least minimized) when we convey multimodal information in a multimodal way, because doing so obviates the need for an attempt to convert what we convey into a verbal code which is by its nature limited in its power of expression. This is because multimodal representations don't attempt to say what they convey, but attempt to show it -i.e. to display it, to exhibit it in a way that presents its essential character. (Groarke, 2017, 23).
\end{abstract}

This capacity of images is the subject of infographics, information and data visualization and information design. One of the greatest exponents of information design stated that «clarity and excellence of thinking is very much like clarity and excellence in the display of data. When principles of design replicate principle of thought, the act of arranging information becomes an act of insight» (Tufte, 1997, 9). ${ }^{9}$

Earlier in history, however, Otto Neurath had the opportunity to develop a project for a universal language based exclusively on signs and pictograms, named «Isotype, the International System of Typografic Picture Education» (Neurath, 1936, 7). This project has recently attracted significant interest ${ }^{10}$ and is based on the hope «to establish a global standard for education and to unite humanity through one ordered, universally readable language of vision» (Lupton, 1986, 47).

However, Neurath was aware that «every language is complex-even the simplest» (Neurath, 1936, 14) and that this applies to both words and images. This is why he was convinced that an organization capable of creating an unambiguous and universal language of images was needed, because

frequently it is very hard to say in words what is clear straight away to the eye. It is unnecessary to say in words what we are able to make clear by pictures; to make a picture is a more responsible work than to make a statement, because pictures make a greater effect and have a longer existence. (Neurath, 1936, 15).

At the same time, he was convinced that (the original text is in capital letters) «WORDS MAKE DIVISION, PICTURES MAKE CONNECTION» (Neurath,

\footnotetext{
${ }^{8}$ And indeed, this might seem to contradict the fact that the function of the law and the rule of law is to protect citizens, although Endicott (2001) has shown that this is not necessarily the case.

${ }^{9}$ In fact, Tufte's argument is more complex, since the intuitive mirroring of data is not the starting point, but the main objective of good infographics (as opposed to the so-called "chartjunk") (Manchia 2011, 590, ft. 3. Our translation).

${ }^{10}$ See https://hyphenpress.co.uk/journal/article/isotype_recent_publications (consulted on 15.4.2021).
} 
1936, 18). On the basis of this conviction, Gerd Arntz created the Isotype visual dictionary with more than 4,000 symbols. ${ }^{11}$

Today, this project is relevant in many ways (e.g. compared to emojis), as Neurath was already aware that «the effect of pictures is frequently greater than the effect of words, specially at the first stage of getting new knowledge» (Neurath, 1936, 22; Cat, 2021). In addition to this, his

idea was that images can bridge differences of language, are easy to grasp and, when done well, also nice to look at. The legibility of Isotype is determined by the simplicity of its symbols. These should be instantly recognizable, without any distracting detail. What counts is the general idea - for common use the precise details are of less importance. Or in Neurath's words: "It is better to remember simplified images, than to forget exact figures". (Bruisnma 2008).

It seems to us that Figs. 9.1 and 9.2 follow Neurath's theory: even though they are addressed to a linguistically different audience (English and Italian speakers) they use the same drawings, and the verbal part of the description does not even appear in the Italian version. Eighty-five years later, after the digital revolution, Neurath's words seem prophetic.

\subsection{The Nature of Images}

In fact, Neurath believed that «an Isotype character is similar to a scientific formula; it is a reduced and conventionalized scheme of direct experience. The picture for Neurath was an intrinsically neutral mode of expression» (Lupton, 1986, 50). But this is just an utopia, because it always exists a cultural framework and today it is clear that, when presented with any image, the spectator always plays an active role in the perception and reconstruction of the image itself (Kandel, 2012). Images are neither "objective" nor neutral.

The same work of creating images, icons and diagrams is far from neutral: Figs. 9.4 and 9.5 might indeed seem neutral and "objective", but they are not. «Nothing is free of rhetoric, that visual manifestations emerge from particular historical circumstances, that ideological vacuums do not exist» (Kinross, 1985, 29,). In other words, «design is inherently rhetorical» (Kostelnick, 2004, 218), because.

a diagram does not imply reproducing, by similarity, certain qualities of an object in the real world but producing a representation of a network of relationships that does not resemble an existing thing, precisely because it creates its own object by visually giving structure and body to a series of data. (Manchia, 2014, 475. Our translation).

Therefore, graphic representation is not merely representative, but creative. There is perhaps no such thing as a representation that is not also a creation. This also applies

\footnotetext{
${ }^{11}$ Gerd Arntz developed the pictograms when he was working at Statistics Netherlands (https://www. cbs.nl/, consulted on 15.4.2021). More information on Gerd Arntz and the collection of his images is now available at http://www.gerdarntz.org./content/gerd-arntz\#isotype, consulted on 15.4.2021 (image 7 is from that website).
} 
to visual information, since it aims to «make certain phenomena and certain aspects of reality visible and comprehensible; many of these phenomena are not naturally accessible to the unaided eye and many are not even visual in nature» (Costa, 1998, 26. Our translation).

On the other hand, diagrams and infographics «are technologies, a means to an end, devices whose aim is to help an audience complete certain tasks» (Cairo, 2013, 23. Our translation). In other words, as it happens with every kind of communication, they have a rhetorical value.

It is for their appearance of objectivity in visual communication, that diagrams and infographics are powerful rhetorical means:

their effectiveness is motivated precisely by the fact that they appear objective, when, in fact, they are not. Today, many of these forms - bar graphs, pie charts, bi-polar diagramshave become so familiar that we don't question their conventional status as genres. This process of enculturation creates rhetorical efficiency as well as poses an interpretive problem because readers come to regard conventional forms as natural, direct representations of fact unmediated by the artificial lens of design. (Kostelnick, 2004, 225, italics by the Author).

However, posters and brochures such as those on hand washing (Figs. 9.1 and 9.2) do appear to be exceptions to what has been stated so far: they do not seem to require any particular interpretation. But for this very reason they are good examples of how the Isotype project has affected the development of contemporary visual information. Indeed,

Isotype exemplifies a project common to much modern art and design - the attempt to eclipse interpretation with perception, to replace reading with seeing. Interpretation involves intellectual confrontation with language and other cultural products. Perception, on the other hand, describes experience in terms of conditioned reactions of the body and brain. [...] As people concerned with the visual, artists and designers tend to focus on perception at the expense of interpretation. (Lupton, 1986, 51).

Nevertheless, once again, it should be noted that «International pictures demand interpretation; they must be read» (Lupton, 1986, 51). Without going into detail, it can actually be argued that even the simplest images may require interpretation: perhaps those that appear in Fig. 9.3 are not immediate, but they become so by virtue of the verbal explanation. Spectators interpret the image once they have perceived it, then the image, given the context, automatically conveys its message. It is like a road sign: when it comes to understanding what the speed limit in a certain area is, the answer is simple, because you just have to look at the sign. In these cases, it seems that, contrary to Dworkin's (1986) statement, understanding does not require interpretation (Patterson, 1996).It is also interesting to remember that Neurath established two rules for Isotype: «reduction, for determining the style of individual signs; and consistency, for giving a group of signs the appearance of a coherent system» (Lupton, 1986, 53). Therefore,

these rules have both explicit, practical functions and implicit, rhetorical functions. These constructive rules project an image of empirical, scientific objectivity [...]. The implicit, rhetorical function of reduction is to suggest that the image has a natural, scientific relationship to its object, as if it were a natural, necessary essence rather than a culturally learned 
sign. [...] And rhetorically, stylistic consistency gives the effect of an ordered, self-sufficient "language". (Lupton, 1986, 53-54; 56).

In the case of Isotype and Figs. 9.1 and 9.2, we can detect a rhetorical purpose, although at first glance the empirical evidence tends to hide this.

\subsection{Italian Pandemic Legislation and Its Soft-Enforcement}

In the previous sections we detailed the main innovative techniques employed by the Italian Government in the context of the Covid-19 pandemic. We shall now make a number of considerations on the small number of sanctions provided for by the legislator and on the idea that normative power of many regulations needed to be reinforced. This thesis maintains that the soft enforcement, ${ }^{12}$ which is subject to the repeated infringement of the formal hierarchy among the norms, has required the legislator to put a great effort into justifying the measures, as they had to motivate and persuade the addressees to obey the hard choices decided upon. In addition to the small number of sanctions provided for, a certain "reluctancy" of the Courts in applying them can be also noted. In order to give a clear picture of this phenomenon it is sufficient to refer to three emblematic pronouncements which occurred in the last 12 months.

1. On 16th November 2020, the Court of Milan ${ }^{13}$ held that any person would be free to make false statements in order to infringe the provisions restricting freedom of movement, without incurring any penalty. The Court held that, if this were not the case, the right of defense (Article 24(2) of the Italian Constitution) would be infringed, and a duty which is against the law, that is to incriminate oneself by a self-certification, would have been imposed.

2. On 25th March 2021, the Court of Milan ruled that it is lawful to lie in order to evade sanctions relating to travel bans, on the basis of the general principle of law that one cannot be punished for his/her own intentions: stating that one is going to a certain destination (however invented) is a mere future intention, and not a fact that has already occurred, and as such is not punishable. ${ }^{14}$

3. On 27th January 2021, the Court of Reggio Emilia ruled that the Ministerial Decree, as a secondary source of legislation, could not provide for the obligation to stay at home and, therefore, the related sanctions could not be imposed. According to the Court, art. 13 paragraph 2 of the Italian Constitution could allow for limitations of personal freedom only if they were established by a

\footnotetext{
${ }^{12}$ We will use the term "soft-enforcement" following the example of Terpan $(2015,10)$, who uses it to refer to circumstances in which compliance by recipients is not ensured through the use or application of coercive or punitive measures.

${ }^{13}$ https://drive.google.com/file/d/1MumUUY1Fz3jnEAMr3MEGatqc6JidYfhI/view, consulted on 6.4.2021.

${ }^{14}$ https://www.sistemapenale.it/pdf_contenuti/1610403797_gip-milano-falso-autocertificazionecovid-483-codice-penale.pdf, consulted on 6.4.2021.
} 
primary source of law and for individual cases, singularly authorized by a judicial authority (but since such Decrees are addressed to the whole citizenship, this would be impossible). ${ }^{15}$

These examples are not intended to suggest that there is (or has been) any sort of 'disconnection' between legislative and judicial activities, but simply that the legislator, being aware of the difficulties of providing for and applying sanctions, had to engage in more argumentative (justifying the rules) and persuasive (convincing citizens to obey) activities than what is normally required.

In order to better understand the scope of the phenomenon, it is possible to make a comparison with the well-known Community soft-law, trying to understand whether it can be superimposed on the case that we are examining, and if so, what are the related consequences in terms of argumentation.

The term "soft law" is generally used to refer to guidelines issued by governments or international organizations to member states or their nationals, without them having full binding force and/or sanctions in the event of non-compliance. Terpan $(2015,71-78)$ defines the traits of soft law by examining two elements which are common to all legal provisions: obligation and enforcement.

The obligation would be the source of the provision and its content. A provision, therefore, could have a soft obligation whenever there is a softness of the source (soft instrumentum) or whenever there is a softness of the content (soft negotium) (this distinction, used by Terpan, 2015, was introduced by d'Aspremont, 2008, 10811087).

On the other hand, the enforcement would be composed of the actions carried out by the legal system for non-compliance: it could be defined as soft whenever there is not a stated sanction or there is not a judicial authority which has the competence (or the will) to impose it.

Finally, it is possible to define as soft law all regulatory provisions that (i) present both the obligation and the enforcement in a soft version (ii) have one of the two elements in a soft version; (iii) present only one of the two elements (in their hard or soft version).

Therefore, it can be argued that the measures implemented during the pandemic are soft law because the enforcement appears to be soft. In fact, for most of the rules there is no provision for a sanction and, even when it is foreseen, the legitimacy of the sanctions and therefore the Courts' willingness to apply it seems questionable.

\subsection{Argumentative Strengthening of Pandemic Legislation}

On the basis of the discussion presented in the previous section on the extensive use of images, the thesis that we would like to support now is that, similar to what happens for community soft-law, the softness of the provisions issued during the pandemic

\footnotetext{
${ }^{15} \mathrm{https} / / /$ canestrinilex.com/risorse/dpcm-non-puo-limitare-liberta-personale-tr-r-emilia-5421/, consulted on 6.4.2021.
} 
has led the Government to put in place an argumentative strengthening, aimed at providing citizens good reasons in order for them to comply with the provisions. Once again, this is a confirmation of the new nature of the legislative action also emerged during the management of the pandemic, more careful to convince citizens than to force them through sanctions. Indeed, this is an excellent example of how the normativity of law depends on moral reasons, a point which has also been stated by experts of the post-Hartian school of legal positivism (Schiavello, 2010).

In fact, in traditional soft law cases, which are characterized by the (total or partial) absence of sanctions, the legislator should be able to convince the recipients of the necessity to comply with the provision (And one \& Greco, 2018). On the other hand, it is evident that a legislator who can rely on the systematic use of coercion does not have the need to justify its choices (Wintgens, 2006: 5; Picchi, 2011; Ferraro \& Zorzetto, 2018); on the contrary, the presence of soft-enforcement would imply a more intense relationship between the legislator and the recipients, based on the ability of the former to persuade the latter (Terpan, 2015, 88).

With reference to Community soft law, the rhetorical-argumentative activity supporting the provision is traditionally contained in the preamble, which is expressly dedicated to the exposition of the factual situation in which the provision is inserted. In the preamble, therefore, by means of precise rhetorical-argumentative patterns, the legislator tends to state (i) that a problem exists or is imminent and it concerns the community, (ii) that the method proposed in the text of the provision is the most effective one to solve or prevent such a problem, (iii) the expected results of compliance with the provision (Andone \& Coman-Kund, 2017).

In the case under consideration, the Law Decrees and the D.P.C.M. do not contain this kind of preamble: on the contrary-as in the case of Article 1 of Law Decree $6 / 2020$ - the reasons given for supporting the regulatory action are summarized in a single statement without explanations: «in order to avoid the spread of COVID$19 » .{ }^{16}$ Therefore, rhetorical strengthening is carried out through a variety of factors which are external to the legislative corpus stricto sensu, namely the aforementioned use of images combined with a peculiar media activity of the legislator. In particular, and in addition to what has been noted on the use of images:

1. The Ministerial Decrees issued between March 2020 and January 2021 were announced live by the President of the Council of Ministers, on national television channels or via his personal pages on social networks. The live broadcasts all repeated the above-mentioned rhetorical-argumentative patterns: (i) they started with a review of the evolution of the pandemic in Italy, even using images and infographics, which rhetorical function was, in this case, to present the problem to be solved (by taking advantages of the resemblance of objectivity assigned to them); (ii) they offered arguments in favor of the measures, depicting them as the most suitable for solving the problem (the justification of the instruments adopted, referring also to pragmatic arguments) (Andone \& Lomeli, 2019); (iii) they presented the goals to be reached during the period in

\footnotetext{
${ }^{16} \mathrm{https} / / /$ www.gazzettaufficiale.it Consulted on 6.4.2021.
} 
which the measures would be operational (the identification of the objective to be achieved).

2. On the Italian Government's website, a page specifically dedicated to FAQs has been set up, containing answers to the most frequently asked questions concerning the interpretation to be given to the provisions issued during the pandemic. ${ }^{17}$ From our standpoint, this section has a clear rhetorical value, since it is aimed at representing the reasons for acting.

Therefore, in line with a broad interpretation of the concept of "legislative activity", capable of encompassing not only the production of legislation itself, but also the activity of rational justification of the norms (Wintgens, 2006, 10), we believe that these factors can be seen as part of the formal activity of the legislator and they consist, precisely, in the argumentative strengthening needed by regulatory instruments endowed with soft-enforcement.

In fact, the live presentation of the Ministerial Decrees, could fulfill the rhetoricalargumentative function aimed at convincing the addressees to abide by the regulation (which is typically performed by the preamble for a soft law).

On the other hand, the FAQ section on the Government's (and therefore the legislator's) website could be a means of disseminating an authentic interpretation of the rules (particularly authoritative and difficult to overcome).

\subsection{The Role Played by the Experts and Their Rhetorical-Argumentative Accountability}

To conclude, we shall make a few observations on the third element we initially identified as a characteristic of the Italian legislative activity during the COVID-19 pandemic, namely the role played by experts.

Haack (2014) explained the complexity of the relationship between science and law; however, we will only consider the position of experts in relation to the argumentative strengthening of the lawmaker through a comparison with soft law at EU level.

With reference to the latter, Rose (2016) expressly speaks of non-binding instruments, which (i) would be particularly appropriate to regulate constantly evolving circumstances and which, for this reason, require flexible regulatory responses; (ii) would be ideal for shorter formulation and revision procedures, as a new agreement among institutional negotiators would be sufficient; (iii) would allow for the active participation of experts in specific disciplines, as there would be no reason for involving just the people's representatives, to the exclusion of others, in the rule-making process.

The question concerning the choice of the most suitable legislative source (implied by (i) and (ii)) does not seem to arise in this case, since the declaration of a state of

\footnotetext{
${ }^{17} \mathrm{http} / / /$ www.governo.it Consulted on 6.4.2021.
} 
emergency has allowed the Italian legislator to resort to legislative instruments which, although potentially binding, can be issued and amended extremely quickly — as is the case with Law Decrees and D.P.C.M.

In our opinion, however, case (iii) is more interesting. Further to this point, the concept of public accountability has been introduced into EU soft law (Bovens, 2006, 9). This explains how technical experts, negotiators or institutional subjects lacking democratic legitimacy can play an active role in the enactment of soft-binding legislation.

With regard to the Italian COVID-19 legislation, the relationship between the members of the C.T.S. and the recipients of the measures developed through the combination of two peculiar ways: the first one can be defined more argumentative, whereas the second one more rhetorical. The argumentative aspect of the activity of C.T.S. (1) concerns "the obligation to explain and to justify", while the rhetorical element (2) concerns the possibility that citizens express their judgment on the "actors" (namely, the members of the C.T.S.) and the latter must bear the consequences (Piazza, 2008, 84-87).

(1) Although the C.T.S. members have never participated in the live media broadcasts of the presentation of the D.P.C.M., the Government-as it did for the FAQ section-has created a section on the Ministry of Health website ${ }^{18}$ which is specifically dedicated to the reports of the C.T.S. meetings. In these weekly reports, several pages of data on the evolution of the pandemic can be found, accompanied by the experts' conclusions which, for each region, identify and briefly justify the risk coefficients, to which the application of various restrictive measures is linked. ${ }^{19}$ The activity of argumentative strengthening of the dispositions does not involve only the Legislator, but also the other institutional subjects who are part of the legislative procedure: as they lack any form of democratic legitimation, they must establish a specific relationship of public accountability on an argumentative basis.

(2) The C.T.S. has a technical-scientific role: this means that its opinions have a precise alethic value. They should meet the alethic rights of the citizen, such as the legitimate claim to know the truth and to be truthfully informed (D'Agostini \& Ferrera, 2017). The fact that the C.T.S. can play the role of a "reliable alethic authority" reinforces its accountability and the citizens' opinion of it, as the following circumstances attest:

II. In order to prevent misleading information from affecting citizens' opinions, the Ministry of Health set up a section specifically dedicated to the complex issue of uncovering fake news, ${ }^{20}$ which has the potential

\footnotetext{
${ }^{18} \mathrm{http}: / /$ www.salute.gov.it/portale/nuovocoronavirus/dettaglioContenutiNuovoCoronavirus.jsp?lin gua $=$ italiano\&id $=5432 \&$ area=nuovoCoronavirus\&menu=vuoto. Consulted on 9.4.2021.

${ }^{19}$ For example, see the link as of 5.4.2021: http://www.salute.gov.it/imgs/C_17_monitoraggi_54_1_ fileNazionale.pdf

${ }^{20} \mathrm{http}: / / \mathrm{www}$. salute.gov.it/portale/nuovocoronavirus/archivioFakeNewsNuovoCoronavirus.jsp.

Consulted on 9.4.2021.
} 
to undermine the alethic value of news just to have a social resonance (Keyes, 2004).

III. On 13th July 2020, the Regional Administrative Court of Lazio declared that the minutes of the C.T.S. meetings must be public, as an expression of the social importance of knowing the truth, because citizens must be able to have all the information necessary to assess and judge legislative choices. $^{21}$

In conclusion, this entails a general reliance on the C.T.S. as an "alethic authority"; it confirms the argumentative strengthening of the provisions in relation to fake news; it judicially recognizes the role played by accountability which, as mentioned, is developed on an argumentative and rhetorical basis.

\subsection{Conclusions}

In this chapter, we have described how the regulatory action to deal with the COVID19 emergency was developed in Italy. From the point of view of political-legislative techniques, we have examined what kind of acts were employed and issues connected with them. Then, we have emphasized three main peculiarities connected with the role of rhetoric as presented by them: frequent use of images; media activity to introduce and justify rules and dispositions; massive involvement of experts. We have analyzed the visual strategies used, showing how they can never be considered objective or neutral, but always have a rhetorical purpose. Finally, we have returned to aspects of the legislation to consider its peculiar legal nature and other argumentative features, including the role of experts. The evolution of the COVID-19 pandemic, together with the social impact it has had, and still has, clearly shows the rhetorical value of political-legislative communication.

It is worth noting that the analysis conducted in this chapter, although it concerns specifically the Italian pandemic situation-which has involved surely emergency circumstances - could represent how rhetoric, in a broad sense, is increasingly taking on a predominant role in the public sphere, also in the provision of legal rules. From a certain point of view, trust in governments has always depended on the rhetorical pisteis of ethos, logos and pathos: but in today's world, this dependence is increasing for the complex reciprocal relationships between legal and scientific knowledge, and multimedia technologies. Nowadays this, to some extent problematic, set of relations among these three components appears to be almost unavoidable. Surely, the scenario presents mutual and interdependent connections which are not easy to manage, to predict and to regulate for several reasons. Sometimes because law seems subjected to a scientific agenda and knowledge or vice versa, while debates appear to be influenced by the multimedia arena or even made by using it. In our opinion, all these situations demand the need to reach new forms of multi- and inter-disciplinary

\footnotetext{
${ }^{21}$ The judgment is available at http://www.quotidianosanita.it/allegati/allegato8935292.pdf. Consulted on 12.4.2021.
} 
approaches among different branches of knowledge, maybe by reaching again the unity of knowledge we have lost during the last centuries.

Acknowledgements This publication is based upon work from COST Action CA-17132 European Network for Argumentation and Public Policy Analysis (http://publicpolicyargument.eu), supported by COST (European Cooperation in Science and Technology).

\section{References}

And one, C., \& Coman-Kund, F. (2017). Argumentative patterns in the European Union's Directives. An effective tool to foster compliance by the Member States? Journal of Argumentation in Context, 6(1), 76-96.

Andone, C., \& Greco, S. (2018). Evading the burden of proof in European Union soft law instruments: The case of commission recommendation. International Journal for the Semiotics of Law-Revue, 79-99.

Andone, C., \& Lomeli, J. A. (2019). Scientific arguments in policy-making. Journal of Argumentation in Context, 8(2), 195-213.

Belardinelli, S., \& Gili, G. (2020). Fidarsi Cinque forme di fiducia alla prova del Covid-19. Mediascapes Journal 15/20.

Bovens, M. (2006). Analysing and accessing public accountability. A conceptual framework. Eurpean Governance Papers C-06-01, pp. 1-37. https://www.ihs.ac.at/publications/lib/ep7.pdf. Accessed April 28, 2021.

Brennen, J. S., Simon, F. M., \& Kleis, N. R. (2021). Beyond (Mis)representation: Visuals in COVID19 misinformation. The International Journal of Press/politics, 26(1), 277-299.

Bruinsma, M. (2008). Gerd Arnzt (1900-1988). http://www.gerdarntz.org./content/gerd-arntz\#iso type. Accessed April 15, 2021.

Cairo, A. (2013). L'arte funzionale, Infografica e visualizzazione delle informazioni. Pearson, Torino Cassese, S. (2021). La regola e l'eccezione. Il Foglio Quotidiano 86:III.

Cat, J. (2021). Otto Neurath. The stanford encyclopedia of philosophy. https://plato.stanford.edu/ archives/spr2021/entries/neurath/. Accessed April 28, 2021.

Costa, J. (1998). La esquemática: visualizar la información. Editorial Paidós

D’Agostini, F., \& Ferrera, M. (2017). La verità al potere. Einaudi.

D'Aspremont, J. (2008). Softness in international law: A self-serving quest for new legal materials. The European Journal of International Law, 19(5), 1075-1093. http://www.ejil.org/pdfs/19/5/ 1700.pdf. Accessed September 1, 2021.

Daston, L. (2014). Beyond Representation. In C. Coopmans, J. Vertesi, M. E. Lynch, \& S. Woolgar (Eds.), Representation in scientific practice revisited (pp. 319-322). MIT Press.

Delmas Marty, M. (1986). Le flou du droit. Presses Universitaires de France.

Dworkin, D. (1986). Law's empire. Harvard University Press.

Endicott, T. A. O. (2001). Vagueness in Law. Oxford University Press.

Ferraro, F., \& Zorzetto, S. (2018). La motivazione delle leggi. Giappichelli.

Gatta, G.L. (2021). Coronavirus, limitazione di diritti e libertà fondamentali, e diritto penale: un deficit di legalità da rimediare. Sistema penale. https://sistemapenale.it/it/opinioni/coronavisuscovid-19-diritti-liberta-fondamentali-diritto-penale-legalita. Accessed May 29, 2021.

Gazzolo, T. (2020). Epidemia o funzione della peste. Endoxa - Prospettive sul presente, 5(24), $45-55$

Groarke, L. (2017). Multimodality and the law. In M. Manzin, F. Puppo, S. Tomasi (Eds.), Multimodality and reasonableness in judicial rhetoric (pp. 5-31). Trento. https://iris.unitn.it/ retrieve/handle/11572/176082/135622/COLLANA\%20QUADERNI\%20VOLUME\%2028.pdf. Accessed April 14, 2012. 
Haack, S. (2014) Evidence matters: Science, proof and truth in the law. University Press

Jasanoff, S. (Ed.). (2004). States of knowledge: The co-production of science and the social order. Routledge.

Kandel, E. R. (2012). The age of insight: The quest to understand the unconscious in art. Random House Publishing Group.

Keyes, R. (2004). The post-truth era. Dishonesty and deception in contemporary life. Macmillan P.

Kinross, R. (1985). The rhetoric of neutrality. Design Issues, 2(2), 18-30.

Kjeldsen, J.E. (2013). Virtues of visual argumentation: How pictures make the importance and strength of an argument salient. In OSSA Conference Archive 89. https://scholar.uwindsor.ca/oss aarchive/OSSA10/papersandcommentaries/89. Accessed April 12, 2019.

Kjeldsen, J.E. (2018). Rhetorical audience studies and reception of rhetoric. Exploring Audiences Empirically. Springer

Kostelnick, C. (2004). Melting-pot ideology, modernist aesthetics, and the emergence of graphical conventions: The statistical atlases of the United States 1874-1925. In C. A. Hill \& M. H. Helmers (Eds.), Defining visual rhetorics. Lawrence

Lupton, E. (1986). Reading isotype. Design Issues, 3(2), 47-58.

Luzzati, C. (2018). Il legislatore argomentante: Sfondi e sottintesi. In F. Ferraro \& S. Zorzetto (Eds.), La motivazione delle leggi (pp. 1-10). Giappichelli.

MacKenzie, D. (2006). An engine, not a camera: How financial models shape markets. MIT Press.

Manchia, V. (2014). Immagini che raccontano storie. Pratiche e strategie di rappresentazione in due esempi di data visualization. Lexia. Rivista Di Semiotica, 17-18, 473-490.

Manchia, V. (2011). Spiegare per immagini. Procedure di rappresentazione e strategie retoriche nell'"information design". In T. Migliore (Ed.), Retorica del visibile. Strategie dell'immagine tra significazione e comunicazione. 3 (pp. 589-603). Contributi scelti. Aracne.

Neurath, O. (1936). International picture language. The first rules of Isotype. Kegan Paul. https:// imaginarymuseum.org/MHV/PZImhv/NeurathPictureLanguage.html. Accessed April, 152021

Patterson, D. (1996). Law and truth. Oxford University Press.

Piazza, F. (2008). La Retorica di Aristotele. Introduzione alla lettura. Carocci

Picchi, M. (2011). L'obbligo di motivazione delle leggi. Giuffrè

Pino, G. (2017). La certezza del diritto nello stato costituzionale. In A. Apostoli (Ed.), Crisi della giustizia e (in)certezza del diritto (pp. 109-125). Editoriale Scientifica.

Puppo, F. (2012). Dalla vaghezza del linguaggio alla retorica forense. Cedam

Rose, C. (2016). Non-binding instruments and democratic accountability. In H. Cullen et al. (eds.), Experts, networks and international law. Cambridge Un. Pr.. https://doi.org/10.2139/ssrn.278 7135. Accessed 12 April, 2019

Schiavello, A. (2010). Perché obbedire al diritto? La risposta convenzionalistica e i suoi limiti. ETS, Pisa

Terpan, F. (2015). Soft law in the European union-The changing nature of EU law. European Law Journal, 21(1), 68-96.

Tufte, E. R. (1997). Visual explanations: Images and quantities. Graphics Press.

Wintgens, L. (2006). Legisprudence as a new theory of legislation. Ratio Juris, 19(1), 1-25. 
Open Access This chapter is licensed under the terms of the Creative Commons Attribution 4.0 International License (http://creativecommons.org/licenses/by/4.0/), which permits use, sharing, adaptation, distribution and reproduction in any medium or format, as long as you give appropriate credit to the original author(s) and the source, provide a link to the Creative Commons license and indicate if changes were made.

The images or other third party material in this chapter are included in the chapter's Creative Commons license, unless indicated otherwise in a credit line to the material. If material is not included in the chapter's Creative Commons license and your intended use is not permitted by statutory regulation or exceeds the permitted use, you will need to obtain permission directly from the copyright holder.

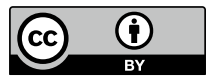

